\title{
Protective effect of selenium on lung cancer in smelter workers
}

\author{
L GERHARDSSON, ${ }^{2}{ }^{3}$ D BRUNE, ${ }^{4}$ I G F NORDBERG,${ }^{2}$ AND P O WESTER ${ }^{1}$
}

From the Departments of Medicine ${ }^{1}$ and Environmental Medicine, ${ }^{2}$ University of Umed, Department of Occupational Medicine, ${ }^{3}$ University Hospital, Umea, Sweden, and Scandinavian Institute of Dental Materials, ${ }^{4}$ Oslo, Norway

\begin{abstract}
A possible protective effect of selenium against lung cancer has been indicated in recent studies. Workers in copper smelters are exposed to a combination of airborne selenium and carcinogens. In this study lung tissue concentrations of selenium, antimony, arsenic, cadmium, chromium, cobalt, lanthanum, and lead from 76 dead copper smelter workers were compared with those of 15 controls from a rural area and 10 controls from an urban area. The mean exposure time for the dead workers was 31.2 years, and the mean retirement time after the end of exposure $7 \cdot 2$ years. Lung cancer appeared in the workers with the lowest selenium lung tissue levels (selenium median value $71 \mu \mathrm{g} / \mathrm{kg}$ wet weight), as compared with both the controls (rural group, median value 110; urban group, median value 136) and other causes of death among the workers (median value 158). The quotient between the metals and selenium was used for comparison: a high quotient indicating a low protective effect of selenium and vice versa. The median values of the quotients between antimony, arsenic, cadmium, lanthanum, lead, chromium, and cobalt versus selenium were all numerically higher among the cases of lung cancer, the first five significantly higher $(p<0.05)$ in 28 of the 35 comparisons between the lung cancer group and all other groups of smelter workers and controls. The different lung metal concentrations for each person were weighted according to their carcinogenic potency $(\mathrm{Crx} 4+\mathrm{Asx} 3+\mathrm{Cdx} 2+\mathrm{Sbx} 1+$ Cox $1+\operatorname{Lax} 1+$ Pbx1) against their corresponding selenium concentrations. From these calculations the protective effect of selenium was even more pronounced.
\end{abstract}

Selenium is an element with remarkable properties. It is toxic at high doses but is also an essential trace element in many species, ${ }^{12}$ including man. ${ }^{3}$ In animals, selenium enhances both primary and secondary immune responses ${ }^{4}$ and reduces the incidence of chemically induced cancers. ${ }^{6-10}$ For example, exposure of female virgin $\mathrm{C}_{3} \mathrm{H} / \mathrm{St}$ mice to two $\mathrm{ppm}$ of selenite in the drinking water for 15 months was found to lower the incidence of spontaneous mammary tumours." Selenium also decreases the mutagenic activity of certain carcinogens ${ }^{12-14}$ and has an inhibitory effect on tumour growth in mice inoculated with Ehrlich ascites tumour cells. ${ }^{15}$

It has been suggested that selenium reduces chemical carcinogenesis in tissue cultures by changing the metabolism and detoxification processes of the cancer inducing agents. ${ }^{16-14}$ Loosely bound to pro-

Received 26 November 1984

Accepted 28 January 1985 tein, selenium may compete with the carcinogen for binding sites at the target organ..$^{20}$ Selenium is a key element in the enzyme glutathione peroxidase, which protects tissues against oxidative damage, ${ }^{21}$ and may have additional antioxidant activity not mediated by this enzyme. ${ }^{22}$ Human data regarding the protective effects of selenium are, however, limited, particularly in the working environment.

The great number of parameters involved in work environment studies make the interpretation of such results difficult. In the present study the concentrations of selenium and some metals with different carcinogenicity have been analysed in lung tissue samples from dead copper smelter workers, and the findings have been related to the diagnoses at the time of death. Special attention has been paid to the development of lung cancer.

OCCURRENCE AND USE

Selenium was discovered in 1817 by Berzelius and 
Gahn in sediments from a sulphuric acid plant at Gripsholm, Sweden. Selenium appears in rocks and soils but cannot economically be recovered from the earth; the chief world supplies come from sediments and sludges from copper refining industries.

Soil concentrations may range from $0.1 \mathrm{mg} / \mathrm{kg}$ in selenium deficient areas to over $1000 \mathrm{mg} / \mathrm{kg}$ in seliniferous areas; values between 1 and $10 \mathrm{mg} / \mathrm{kg}$ are commonly found. Selenium in drinking water rarely exceeds $10 \mu \mathrm{g} / \mathrm{l}$ but high values have been found in some alkaline waters. ${ }^{23}$

Selenium is commercially used in many products from the electronic, glass, pigment, rubber, and chemical industries but more than half the world production of selenium goes to the manufacture of selenium rectifiers. It is used for alloying with stainless steel and copper, as an additive in the natural and synthetic rubber industries, and also as an insecticide. Inorganic salts of selenium are used as feed additives. Selenium sulphide preparation are used in human medicine for external application and selenium radionuclides are used in the scanning of organs and tissues. ${ }^{24}$

\section{Uptake}

Selenium is a semi-metal or metalloid, similar to sulphur in its chemical properties. Selenium compounds may be absorbed in toxic quantities through the lungs, intestinal tract, or damaged skin but it is also an essential element in the enzyme glutathione peroxidase. There are wide geographical variations in the daily intake of selenium with food and water; from 60 to $300 \mu \mathrm{g} /$ day. ${ }^{23}$ The dietary daily intake of selenium in Sweden is comparatively low, about 30 $\mu \mathrm{g}$; most is from meat, liver, kidney, fish, and shell fish. Stewart et al found that people absorbed about $80 \%$ of their dietary selenium intake. ${ }^{25}$ In man $93 \%$ of the selenium was absorbed when milligram doses of aqueous sodium selenite were administered. ${ }^{24}$

\section{Excretion}

Selenium is mainly excreted in the urine. When administered in large doses a high proportion is rapidly eliminated from the organism within the first day. The first rapid phase is followed after a transition period, by a slower elimination phase representing the long term whole body turnover of selenium. Limited human data indicate an excretion rate during the later phase with a half time of 103 and 234 days for selenite and selenomethionine respectively. ${ }^{26}$ Excretion is influenced by the dietary selenium intake.

The whole body selenium content in adults estimated by three different methods gave values of about 3-6 mg. ${ }^{25}$ Selenium has been found in all necropsy samples of human organs and tissues analysed. The highest values were found in the kidney (100$1170 \mu \mathrm{g} / \mathrm{kg}$ wet weight), followed by the liver (97$680 \mu \mathrm{g} / \mathrm{kg}$ wet weight); heart and lung values were somewhat lower and of the same magnitude (70$280 \mu \mathrm{g} / \mathrm{kg}$ wet weight). ${ }^{27}$ Results from different countries are reviewed by Masironi and Parr. ${ }^{28}$ Data reported from Sweden were for kidney (370-1030 $\mu \mathrm{g} / \mathrm{kg}$ wet weight), liver $(140-460 \mu \mathrm{g} / \mathrm{kg}$ wet weight), lung (44-700 $\mu \mathrm{g} / \mathrm{kg}$ wet weight), and for heart (97-250 $\mu \mathrm{g} / \mathrm{kg}$ wet weight). ${ }^{29} 30$

Investigations of acute and chronic selenosis in several animal species showed that the highest concentrations of selenium were in the liver, and in decreasing order in kidneys, spleen, and lungs. Small amounts of selenium were found in the myocardium, skeletal muscles, and brain. Fat was practically free of selenium. ${ }^{31}$

\section{Selenium and cancer}

Several epidemiological studies have shown a protective effect of selenium against cancer. In geographical areas with high selenium concentrations (determined in blood and forage crops) age specific death rates for cancer are lower than in areas with lower concentrations..$^{32-34}$ The high selenium areas studied were, however, the least industrialise Shamberger et al compared American cities an states having different selenium concentrations. ${ }^{33}$ I places high in selenium they observed significantly lower death rates for cancer for white men with neoplasms of the tongue, oesophagus, stomach, intestine, rectum, liver, pancreas, larynx, lungs, kidneys, and bladder. Lower death rates were also observed for patients with Hodgkin's disease and lymphoma. Blood selenium concentrations after cancer had been diagnosed were lower for the patients with cancer than for the controls. $.^{32} 35-37$ The cancer may, however, affect the general nutritional state and consequently the selenium concentrations. In an extensive study Willett et al were able to determine blood selenium concentrations before cancer was diagnosed. ${ }^{38}$ Blood samples from a great number of people were collected in 1973. In their material 111 patients who developed cancer during the next five years could be compared with 210 cancer free subjects, all matched for age, race, sex, and smoking habits. The patients with cancer had significantly lower blood selenium concentrations with the strongest association between low selenium and gastrointestinal and prostatic cancers.

In current reports the development of cancer is mainly related to selenium in the blood and not in the target organs. Our studies of tissue concentra- 
tions might consequently add some further information.

\section{Potentially carcinogenic metals}

Selenium was earlier considered as a suspect carcinogen; this has not been confirmed, however. On the contrary, there is increasing evidence of its protective properties. We have tried to link the protective effect of selenium to the elements antimony, arsenic, cadmium, chromium, cobalt, lanthanum, and lead for the following reasons.

Arsenic-An increased incidence of lung cancer has been associated with exposure to arsenic..$^{39-45} \mathrm{~A}$ Swedish case-referent study of smelter workers indicated that the highest observed incidence was due to the combined effect of smoking and exposure to arsenic at certain workplaces. ${ }^{46}$ Sulphur oxides and organic carcinogens may also contribute. ${ }^{47}$ Experimental evidence in animals is now available concerning a carcinogenic effect after exposure to a combination of arsenic trioxide and sulphate. An enhancement of the occurrence of adenomatous tumours from the exposure to benzo(a)pyrene when combined with arsenic was also indicated in these studies. ${ }^{48}$ The smelter workers in question were simultaneously exposed to arsenic, sulphur dioxide, and 3, 4 benzo(a)pyrene.

Chromium-Smelter workers are exposed to fumes containing both $\mathrm{Cr}$ (III) and $\mathrm{Cr}(\mathrm{VI})$ compounds of different solubility. We have not been able to determine the exact proportions at the different worksites but have found that the hexavalent chromium part of the fumes has a reduced solubility enabling it to remain in the lungs for a long period. Numerous animal and epidemiological studies give evidence of the carcinogenicity of hexavalent chromium..$^{49-58}$

Cadmium is shown to be carcinogenic in experimental animal studies. ${ }^{59-61}$ In man an association between exposure to cadmium and prostatic cancer has been reported..$^{60}$ An increased risk of lung cancer among cadmium smelter workers has been indicated. ${ }^{63}$ Final conclusions are, however, still lacking.

Zinc is not associated with risks of cancer. Dietary zinc, however, can effect both enhancement and inhibition of carcinogenicity, depending on dietary concentrations. ${ }^{10}$

Lanthanum has not been related to cancer.

Antimony has not been connected with human cancer risks but a recent animal study suggests that antimony may significantly contribute to the development of lung cancer (WD Watt, EJ Kerfoot, paper presented at 21st Annual American Industrial Hygiene Conference, Portland, 1981).
Lead-The carcinogenic properties of lead are still not clear. In animal experiments lead salts have caused cancer. ${ }^{64}$ os Earlier epidemiological studies have not shown an increased risk of cancer even in heavily exposed groups of workers. Workers exposed to tetraethyl lead show no increased risk of cancer. A slightly increased risk for lung cancer among lead smelter workers but not battery workers has been reported..$^{66}$ The study has, however, been questioned. ${ }^{68}$

\section{Protective effects of selenium}

In all living cells active and short lived free radicals - superoxide anion radicals, for exampleare formed during oxygen metabolism. Free radicals from atoms, atomic groups, and molecules contain unpaired electrons in an outer orbital. Enzymatic control systems protect the cellular components from the destructive effect of free radicals through various scavenging mechanisms. Selenium is a constituent in such enzymes-for example, glutathione peroxidase. They form a first line of defence in the protection of oxygen depending organisms and are apparently backed up by other antioxidants such as ceruloplasmin, vitamin $\mathrm{E}$, glutathione, B-carotene, vitamin A, lactoferrin, certain trace elements, such as selenium and magnesium, some thiol containing amino acids, ${ }^{69}$ and proteins such as metallothionein. ${ }^{70}$ Selenium and vitamin $\mathrm{E}$ also protect biological membranes from uncontrolled lipid peroxidation. ${ }^{71}$ The harmful effects of oxygen metabolites are supposed to be defended at three distinct levels:

(1) The selenoenzyme glutathione peroxidase controls intracellular $\mathrm{H}_{2} \mathrm{O}_{2}$ levels in mitochondria and cytoplasm;

(2) Vitamin E prevents the disarray of membrane architecture by inhibiting peroxidation of polyunsaturated fatty acyl residues in membrane phospholipids initiated by oxygen metabolites; and

(3) Glutathione peroxidase catalyses the reduction of polyunsaturated fatty acyl hydroperoxides to the corresponding alcohols. (AT Diplock, paper presented at International Symposium on Health Effects and Interactions of Essential \& Toxic elements, Lund, Sweden, 1983). Selenium is, in other words, an interesting element in different defence mechanisms in the human body. Selenium also binds metals in metal complex compounds not harmful to the body.

\section{Material and methods}

The Rönnskär copper smelter in the north of Sweden was established in 1930 . The annual production of selenium in 1983 was around $50000 \mathrm{~kg}$. 
Exposure to selenium in the working environment is highest in the arsenic department, the selenium department, the roasters, the copper smelting furnace, the electrolysis plant, and the precious metal works. The turnover of workers has, on average, been rather low and many of the workers have been working in the smelter up to their pension age. The Swedish health registration systems are fairly complete and enable life long health studies to be undertaken.

\section{MATERIAL}

Through close cooperation with the Rönnskär company health service and the local hospital in Skellefteå lung tissue samples could be collected in connection with routine necropsies. Our material consists of 76 male copper smelter workers consecutively dead after April 1975, no regard being taken of cause of death diagnoses.

\section{METHOD}

Samples of about $2 \mathrm{~g}$ wet weight were taken by the same technican from the lowest part of the right upper lung lobe. Quartz instruments were used to avoid contamination. The samples were transferred to cleaned quartz ampoules and freeze dried. The ampoules for neutron activation analysis were then sealed in a flame and later irradiated with a thermal neutron flux of $2 \times 10^{13} \mathrm{n} /\left(\mathrm{cm}^{2} . \mathrm{s}\right)$ for three days (R2 reactor, Studsvik) or $5 \times 10^{12} \mathrm{n} /\left(\mathrm{cm}^{2} . \mathrm{s}\right)$ for two days (Kjeller, Norway). The radionuclides from selenium, antimony, arsenic, cadmium, chromium, cobalt, and lanthanum were chemically separated with an automated ion exchange technique. Gamma spectrometric measurements were carried out on the separated fractions as described by Samsahl et al. ${ }^{72}$ The group separation method was checked with specimens of the NBS bovine liver and was found to be satisfactory for the certified element levels.

The reliability of the group separation techniques in the nuclear analysis of biological specimens has previously been studied by Wester $e^{2}$ al $^{73}$ and Samsahl $e a^{l^{2}}$ and found to be satisfactory. The neutron activation analyses were performed at Studsvik, Sweden, and also by Tekniska Röntgencentralen AB, Stockholm, and Institutet för Vatten och Luftvårdsforskning, Stockholm, Sweden. The accuracy in the measurements of all elements measured with neutron activation analysis is within $\pm 10 \%$ (J Werner, Institutet fơr Vatten och Luftvårdsforskning, personal communication 1983).

Lead was analysed by atomic absorption spectrophotometry at the department of hygiene at the Karolinska Institutet, Stockholm, and at the department of analytical chemistry, Umeå, Sweden. ${ }^{74}$ The accuracy of these measurements is approximately within $\pm 10 \%$ as the values are far $\bar{z}$ above the detection limit.

\section{Controls}

For comparison tissue samples were taken from a $\stackrel{\vec{P}}{\rightarrow}$ control group of 15 age matched men from a nearby rural area some $50 \mathrm{~km}$ from the smelter (Burträsk 음 and Jörn). Another control group of 10 age matched $\frac{\text { क }}{\triangle}$ men was taken from the city of Stockholm $800 \mathrm{~km} \unrhd$ from the smelter.

\section{Occupations}

Detailed data regarding occupations, duration of $\bar{\omega}$ employments, and so on, were obtained from the Boliden Mining company. Smoking habits were $\frac{\mathbb{}}{3}$ obtained from questionnaires answered by the workers' relatives.

\section{Grouping}

The diagnoses from medical records and necropsy $\stackrel{\circ}{7}$ protocols were divided into groups and subgroups as $\vec{D}$ follows:

Group $1 A$-Death from lung cancer $(\mathrm{n}=7)$.

Group $1 B$-Death from gastrointestinal cancer $(\mathrm{n} \stackrel{\mathbb{8}}{3}$ $=11)$.

Group $1 C$-Death from other malignancies $(\mathrm{n}=\overrightarrow{\vec{C}}$ 7).

Group 2A-Death from cardiovascular diseas $(\mathrm{n}=38)$.

Group 2B-Death from cerebrovascular diseas $(\mathrm{n}=8)$.

Group 2C-Death from other causes $(\mathrm{n}=5)$.

Group $3 A-$ Controls from Burträsk and Jörn (n $\stackrel{\triangle}{\triangle}$ $=15$ ).

Group 3B-Controls from Stockholm $(\mathrm{n}=10)$.

\section{Statistics}

A non-parametric statistical method was used to compare the lung tissue concentrations of the ele- 3 ments under study as trace elements in tissues usu- $\overline{-}$ ally have a skewed distribution..$^{29} 76$ KruskalWallis's one-way analysis of variance and Mann- $\delta$ Whitney's U test were used. Median values for the elements and for the quotients between the differento elements and selenium were calculated. Kruskal- $>$ Wallis's one-way analysis of variance was also used을 to compare mean age, exposure time, and duration of retirement as the group sizes and variances varied क considerably. If Kruskal-Wallis's one-way analysis 0 showed a significant difference $(p<0.05)$ between ${ }_{\omega}^{N}$ the groups the difference was evaluated furthero using pairwise comparisons (Mann-Whitney's test), testing the hypothesis of lower lung selenium concentrations in the lung cancer group. 
Results

\section{MEAN AGE}

Mean age of the smelter workers and the controls, their duration of retirement, and the duration of exposure for the workers are presented in table 1 . The mean age (range 66-71) did not differ significantly between the exposed groups and the controls.

\section{RETIREMENT}

The duration of retirement (time from ended exposure to death) varied between 0 and 23 years. The shortest length of retirement was in group 1C (death from other malignancies) and 2A (death from cardiovascular diseases).

\section{EXPOSURE}

There were only minor differences in the duration of exposure (equated with duration of employment) between the six groups of smelter workers.

\section{CAUSES OF DEATH}

The number of lung cancers in our material is relatively small, seven out of 76 (around $9 \%$ ). The total number of dead workers from the smelters (193082 ) is 1275 with 106 cases of lung cancer (around $8 \%$ ). Our material is thus in agreement with the overall frequency of lung cancer.

Of the smelter workers, $33 \%$ died from different malignancies and $14 \%$ from gastrointestinal cancer; $50 \%$ died from cardiovascular diseases, $11 \%$ from cerebrovascular diseases, and $7 \%$ from other causes. Of the 15 controls from Burträsk and Jörn, 80\% died from cardiovascular diseases and $20 \%$ from cerebrovascular diseases. All 10 controls from Stockholm died of cardiovascular diseases.

\section{TISSUE CONCENTRATIONS}

\section{Elements}

The median values of the elements studied in the lung tissues are summarised in table 2; the median values of the quotient between the different elements and selenium are presented in table 3.

\section{Selenium}

Table 2 shows that the median values of selenium in lung tissue is lower in group 1A (death from lung cancer) than in the other groups of smelter workers and controls. The lung tissue concentrations of selenium in group $1 \mathrm{~A}$ are significantly lower than in groups $1 \mathrm{C}$ and $2 \mathrm{~A}(\mathrm{p}<0.05)$ and numerically lower than in the other groups (Mann-Whitney).

\section{Cadmium}

The lung values of cadmium are significantly higher in group $1 \mathrm{~A}$ than in the other groups of smelter workers (groups $1 \mathrm{~B}, 2 \mathrm{~B} p<0.02$; group $1 \mathrm{C} p<$ 0.05 ; group $2 \mathrm{C} p<0.03$ ) and controls (group $3 \mathrm{~A} \mathrm{p}$ $<.0 .01)$ and numerically higher than in groups $2 \mathrm{~A}$

Table 1 Mean age, duration of retirement, and duration of exposure in smelter workers and controls

\begin{tabular}{|c|c|c|c|}
\hline Mean values $( \pm S D)$ & $\begin{array}{l}\text { Mean age } \\
\text { (years) }\end{array}$ & $\begin{array}{l}\text { Duration of } \\
\text { retirement } \\
\text { (years) }\end{array}$ & $\begin{array}{l}\text { Duration of } \\
\text { exposure } \\
\text { (years) }\end{array}$ \\
\hline $\begin{array}{l}\text { Group } \\
\text { Lung cancer } \\
\text { Gastrointestinal cancer } \\
\text { Other cancers } \\
\text { Cardiovascular disease } \\
\text { Cerebrovascular disease } \\
\text { Other causes } \\
\text { All workers } \\
\text { Controls (rural) } \\
\text { Controls (urban) }\end{array}$ & $\begin{array}{r}68.3 \pm 3.4 \\
71.3 \pm 8.6 \\
67.6 \pm 7.6 \\
67.3 \pm 9.1 \\
68.9 \pm 7.2 \\
66.0 \pm 19.5 \\
68.1 \pm 9.1 \\
67.7 \pm 10.1 \\
68.8 \pm 6.1\end{array}$ & $\begin{array}{r}7.9 \pm 7.5 \\
9.9 \pm 6.6 \\
5.3 \pm 4.9 \\
5.9 \pm 5.2 \\
8.6 \pm 4.6 \\
11.2 \pm 7.7 \\
7.2 \pm 5.9 \\
-\end{array}$ & $\begin{array}{l}30.4 \pm 8.3 \\
31.7 \pm 7.7 \\
32.1 \pm 5.3 \\
32.1 \pm 9.3 \\
29.6 \pm 6.2 \\
25.8 \pm 10.5 \\
31.2 \pm 8.4 \\
-\end{array}$ \\
\hline
\end{tabular}

Table 2 Median selenium, antimony, arsenic, cadmium, chromium, cobalt, lanthanum, and lead concentrations in lung tissue in smelter workers (groups $1 A-2 C$ ) and controls (groups $3 A-3 B)$. (All values in ppb ( $\mu$ g/kg wet weight))

\begin{tabular}{|c|c|c|c|c|c|c|c|c|}
\hline \multirow[t]{2}{*}{ Group } & \multicolumn{8}{|c|}{ Element } \\
\hline & Se & $S b$ & As & $C d$ & $\mathrm{Cr}$ & Co & $L a$ & $P b$ \\
\hline $\begin{array}{l}1 \mathrm{~A} \\
1 \mathrm{~B} \\
1 \mathrm{C} \\
2 \mathrm{~A} \\
2 \mathrm{~B} \\
2 \mathrm{C} \\
\text { All workers } \\
3 \mathrm{~A} \\
3 \mathrm{~B}\end{array}$ & $\begin{array}{r}71 \\
123 \\
175 \\
159 \\
142 \\
215 \\
151 \\
110 \\
136\end{array}$ & $\begin{array}{r}450 \\
376 \\
480 \\
181 \\
355 \\
100 \\
280 \\
32 \\
19\end{array}$ & $\begin{array}{r}40 \\
51 \\
49 \\
34 \\
40 \\
29 \\
38 \\
7 \\
5\end{array}$ & $\begin{array}{r}390 \\
76 \\
63 \\
246 \\
114 \\
108 \\
162 \\
39 \\
79\end{array}$ & $\begin{array}{l}330 \\
470 \\
650 \\
400 \\
455 \\
400 \\
410 \\
110 \\
199\end{array}$ & $\begin{array}{r}15 \\
23 \\
21 \\
16 \\
16 \\
15 \\
16 \\
7 \\
11\end{array}$ & $\begin{array}{r}6.5 \\
8.4 \\
12.8 \\
11.0 \\
8.4 \\
6.2 \\
10.1 \\
5.0 \\
10.0\end{array}$ & $\begin{array}{r}320 \\
140 \\
197 \\
141 \\
151 \\
130 \\
140 \\
55 \\
39\end{array}$ \\
\hline
\end{tabular}


and 3B (Mann-Whitney). For the other metals under study there are no significant differences between the different groups of smelter workers.

\section{All metals}

For all the metals studied, the lung values for all smelter workers are significantly higher than for the controls from the rural area (antimony, arsenic, cadmium, cobalt, lead $\mathrm{p}<0.001$; chromium $\mathrm{p}=$ 0.003 ; lanthanum $p=0.025$; selenium $p=0.016$; Mann-Whitney). The lung tissue content of antimony, arsenic, and lead is significantly higher for all smelter workers compared with the controls from the urban area $(p<0.001)$. Among the controls, the lung values of cobalt $(p<0.05)$ and lanthanum $(p=$ 0.018 ) are significantly lower in group $3 \mathrm{~A}$ than in group 3B. For the other metals no significant differences in lung values were found when comparing the control group from the rural area with the group from Stockholm.

\section{Element quotients}

The quotients between two skewly distributed elements most likely follow a skew distribution. The protective effect of selenium might be visualised as a quotient between the elements with carcinogenic properties, antimony, arsenic, cadmium, chromium, cobalt, lanthanum, lead, and the protective element selenium. A high quotient corresponds to a low protective effect and vice versa. Table 3 shows that the median values of the quotients between antimony, arsenic, cadmium, chromium, cobalt, lanthanum, lead, and selenium in lung tissue are higher in group $1 \mathrm{~A}$ than in all other groups of smelter workers and controls. The quotients $\mathrm{Sb} / \mathrm{Se}, \mathrm{As} / \mathrm{Se}(\mathrm{p}<0.001)$ and $\mathrm{Cd} / \mathrm{Se}, \mathrm{Cr} / \mathrm{Se}, \mathrm{Co} / \mathrm{Se}(\mathrm{p}<0.03)$ for all smelter workers are significantly higher than for the controls from the rural area (Mann-Whitney). When all smelter workers are compared with the controls from the urban area the same pattern is evident for the quotients $\mathrm{Sb} / \mathrm{Se}, \mathrm{As} / \mathrm{Se}$, and $\mathrm{Pb} / \mathrm{Se}(\mathrm{p}<0.001)$. When comparing the control groups, the quotient $\mathrm{La} / \mathrm{Se}$ is significantly lower in group $3 \mathrm{~A}$ than in group 3B $(p<0.05)$. For the other metals the differences for the quotients are not significant when the two control groups are compared.

\section{Analysis of variance}

Kruskal-Wallis's one-way analysis of variance shows a difference between the studied groups for the quotients $\mathrm{Sb} / \mathrm{Se}, \mathrm{As} / \mathrm{Se}(\mathrm{p}<0.001) ; \mathrm{Cd} / \mathrm{Se}(\mathrm{p}=0.003)$; $\mathrm{La} / \mathrm{Se}(\mathrm{p}=0.024)$, and $\mathrm{Pb} / \mathrm{Se}(\mathrm{p}=0.001)$. Table 4 summarises the significance in differences when groups $1 \mathrm{~B}$ to $3 \mathrm{~B}$ are tested (Mann-Whitney) against group 1A. As may be seen from the table, group 1A has significantly higher quotients $(p<0.05)$ than the other groups in 28 of 35 comparisons, corresponding to a low protective effect of selenium.

\section{Additive effect}

If an additive effect is supposed the following calculation is valid:

Table 3 Median values of quotients in lung tissue in smelter workers (groups $1 A-2 C$ ) and controls (groups $3 A-3 B)$

\begin{tabular}{|c|c|c|c|c|c|c|c|}
\hline \multirow[t]{2}{*}{ Group } & \multicolumn{7}{|c|}{ Quotient } \\
\hline & $\mathrm{Sb} / \mathrm{Se}$ & As/Se & $\mathrm{Cd} / \mathrm{Se}$ & $\mathrm{Cr} / \mathrm{Se}$ & ColSe & La/Se & $\mathrm{Pb} / \mathrm{Se}$ \\
\hline $\begin{array}{l}1 \mathrm{~A} \\
1 \mathrm{~B} \\
1 \mathrm{C} \\
2 \mathrm{~A} \\
2 \mathrm{~B} \\
2 \mathrm{C} \\
\text { All workers } \\
3 \mathrm{~A} \\
3 \mathrm{~B}\end{array}$ & $\begin{array}{l}4.53 \\
3.27 \\
2.43 \\
1.06 \\
1.92 \\
0.47 \\
1.59 \\
0.29 \\
0.20\end{array}$ & $\begin{array}{l}0.87 \\
0.38 \\
0.26 \\
0.19 \\
0.25 \\
0.12 \\
0.23 \\
0.05 \\
0.04\end{array}$ & $\begin{array}{l}8.09 \\
0.76 \\
0.51 \\
1.40 \\
0.85 \\
0.61 \\
1.30 \\
0.34 \\
0.70\end{array}$ & $\begin{array}{l}5 \cdot 15 \\
4.09 \\
3.20 \\
1.66 \\
4 \cdot 82 \\
1.86 \\
2.41 \\
0.88 \\
1 \cdot 65\end{array}$ & $\begin{array}{l}0.21 \\
0.20 \\
0.09 \\
0.10 \\
0.11 \\
0.08 \\
0.10 \\
0.05 \\
0.09\end{array}$ & $\begin{array}{l}0.21 \\
0.07 \\
0.07 \\
0.06 \\
0.04 \\
0.03 \\
0.07 \\
0.05 \\
0.08\end{array}$ & $\begin{array}{l}2.28 \\
1.10 \\
0.79 \\
0.81 \\
0.83 \\
0.56 \\
0.83 \\
0.58 \\
0.25\end{array}$ \\
\hline
\end{tabular}

Table $4 p$ Values for differences in quotients when group $1 A$ is tested against other groups (Mann-Whitney's $U$-test)

\begin{tabular}{|c|c|c|c|c|c|}
\hline \multirow[t]{2}{*}{ Groups } & \multicolumn{5}{|l|}{ Quotient } \\
\hline & $\mathrm{Sb} / \mathrm{Se}$ & As/Se & $C d / S e$ & $L a / S e$ & $\mathrm{~Pb} / \mathrm{Se}$ \\
\hline 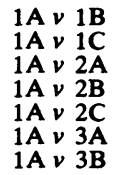 & $\begin{array}{l}\text { NS } \\
\text { NS } \\
0.033 \\
\text { NS } \\
\text { NS } \\
<0.001 \\
<0.001\end{array}$ & $\begin{array}{l}\text { NS } \\
\text { NS } \\
0.013 \\
0.049 \\
0.028 \\
<0.001 \\
0.001\end{array}$ & $\begin{array}{r}0.003 \\
0.009 \\
0.003 \\
0.008 \\
0.005 \\
<0.001 \\
0.011\end{array}$ & $\begin{array}{l}0.016 \\
0.046 \\
0.007 \\
0.039 \\
0.006 \\
0.005 \\
\text { NS }\end{array}$ & $\begin{array}{l}0.009 \\
0.022 \\
0.002 \\
0.010 \\
0.006 \\
0.002 \\
0.001\end{array}$ \\
\hline
\end{tabular}

NS $=$ Not significant. 
$\mathbf{P}_{\text {tot }}=(\mathrm{Sb}$-value + As-value $+\mathrm{Cd}$-value $+\mathrm{Cr}$-value

+ Co-value + La-value $+\mathrm{Pb}$-value $) / \mathrm{Se}$-value.

The higher the $P_{\text {tot }}$, the less the protective effect of the selenium.

Table 5 shows that the median value of $P_{\text {tot }}$ in lung tissues is higher in group $1 \mathrm{~A}$ than in the other groups of smelter workers and controls. The values in group $1 \mathrm{~A}$ are significantly higher than in all other compared groups except in group 1C (dead from other malignancies). As may be seen from table 5 , selenium would reduce a supposed additive effect from the metals under consideration.

\section{Weighting}

As the metals used have different carcinogenic potencies a weighting of the metals may also be considered. We have looked at possible differences in potency by scoring them from 1 to 4 . Chromium was given the score 4 (strongest carcinogenic potency), arsenic 3 , cadmium 2 , and antimony, cobalt, lanthanum, and lead 1.

From this we get the following equation:

$P_{\text {tot }}=[($ Sb-value $\times 1)+($ As-value $\times 3)+(\mathrm{Cd}-$ value $\times 2)+$

$+(\mathrm{Cr}$-value $\times 4)+($ Co-value $\times 1)+(\mathrm{La}-$ value $\times 1)+$

$$
+(\mathrm{Pb} \text {-value } \times 1)] / \text { Se-value. }
$$

The scoring will have an impact on all eight groups under study, exaggerating analytical differences in both positive and negative directions. As may be seen from table 6 , however, the tendency shown in table 5 is maintained.

\section{Smoking infuence}

Of the seven cases with lung cancer, there were three squamous cell carcinomas, two anaplastic carcinomas, one adenocarcinoma, and one unspecified tumour. Four were smokers, two ex-smokers, and one non-smoker (squamous cell carcinoma). Among the smelter workers were 23 smokers, 25 exsmokers, 25 non-smokers, and three with unknown smoking habits. The controls from Jörn and Burträsk had two smokers, two ex-smokers, 10 nonsmokers, and one with unknown smoking habits. Among the controls from the city of Stockholm there were one smoker, one non-smoker, and eight with unknown smoking habits.

The lung tissue concentrations of the studied metals did not differ significantly between smokers, ex-smokers, and non-smokers among the smelter workers except for cadmium which was significantly raised among the smokers $(p<0.001)$.

\section{Discussion}

The smelter workers in the present study were, for many years, exposed to several carcinogenic compounds of inorganic and organic origin. Inhalation has been the main route of exposure and the lungs the most important target organ. The metals involved in the exposure have both weak and strong carcinogenic properties. The fumes also contain other potentially carcinogenic substances, polyaromates from oven electrodes, for example. These substances might add a further risk to workers

Table 5 Median values for $P_{\text {tot }}$ in lung tissue in smelter workers (groups $1 A-2 C$ ) and controls (groups $3 A-3 B$ ). $p$ Values for differences in $P_{\text {tot }}$ when group $1 A$ is tested against other groups (Mann-Whitney's $U$ test)

\begin{tabular}{lcll}
\hline Group & Ptot median value & Groups compared & $p$ Value \\
\hline 1A & 24.4 & - & - \\
1B & 11.3 & $1 \mathrm{~A} v$ 1B & 0.021 \\
1C & $8 \cdot 1$ & $1 \mathrm{~A} v$ 1C & NS \\
2A & 7.2 & $1 \mathrm{~A} v$ 2A & 0.001 \\
2B & 10.0 & $1 \mathrm{~A} v$ 2B & 0.014 \\
2C & 3.8 & $1 \mathrm{~A} v$ 2C & 0.006 \\
3A & 3.6 & $1 \mathrm{~A} v$ 3A & 0.002 \\
3B & 4.8 & $1 \mathrm{~A} v$ 3B & 0.007 \\
\hline
\end{tabular}

NS $=$ Not significant.

Table 6 Median values for $P_{\text {tot }}$ in lung tissue in smelter workers (groups 1A-2C) and controls (groups 3A-3B) after scoring. $p$.Values for differences in $P_{\text {tot }}$ when group $1 A$ is tested against other groups (Mann-Whitney's $U$ test)

\begin{tabular}{|c|c|c|c|}
\hline Group & $P_{\text {tot }}$ median value & Groups compared & p Value \\
\hline $\begin{array}{l}1 \mathrm{~A} \\
1 \mathrm{~B} \\
1 \mathrm{C} \\
2 \mathrm{~A} \\
2 \mathrm{~B} \\
2 \mathrm{C} \\
3 \mathrm{~A} \\
3 \mathrm{~B}\end{array}$ & $\begin{array}{r}56 \cdot 2 \\
24.9 \\
20.1 \\
17 \cdot 3 \\
27.6 \\
10.1 \\
7.7 \\
12.4\end{array}$ & 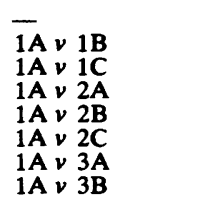 & $\begin{array}{l}\overline{0.035} \\
\text { NS } \\
0.005 \\
0.039 \\
0.011 \\
0.004 \\
0.017\end{array}$ \\
\hline
\end{tabular}

NS $=$ Not significant. 
exposed long term. Selenium is reported effectively to reduce the effect of benzo(a)pyrene in animal studies. ${ }^{77}$

We have noted that the cases of lung cancer in our study showed the lowest selenium content in the lungs compared with both the controls and with other causes of death among the workers. The two lowest lung selenium concentrations in our material were found in the lung cancer group. If a protective effect of selenium is seen as a quotient between the elements studied and selenium the lung cancer group has significantly higher quotients than the other groups in 28 of 35 comparisons for the quotients $\mathrm{Sb} / \mathrm{Se}, \mathrm{As} / \mathrm{Se}, \mathrm{Cd} / \mathrm{Se}, \mathrm{La} / \mathrm{Se}$, and $\mathrm{Pb} / \mathrm{Se}$ corresponding to a low protective effect of selenium. The tendency is maintained if an additive or scoring model is applied. A causal interpretation of our findings is supported by many animal experiments showing the anticarcinogenic effect of selenium. ${ }^{6-1115^{18} 19}$ Furthermore, lower age specific cancer death rates have been reported in geographical areas with high selenium concentrations in blood and forage crops. ${ }^{32-34}$ A protective effect of selenium has also been suggested in several studies showing lower selenium concentrations among patients with cancer compared with cancer free controls. ${ }^{32} 35-38$

The protective effect of selenium might be related to exposure exceeding normal values in the population and the biological half time of the elements under consideration.

\section{Normal values}

The occurrence of metals in subjects from different populations has been poorly studied but there are some reports on normal values from several geographical areas. The lung concentrations in our rural group,3A and urban group, and 3B agree with or are slightly lower than from similar populations reported elsewhere. ${ }^{27} 78$ The lung values of cobalt and lanthanum are significantly lower in group $3 \mathrm{~A}$ than in group 3B. For the other metals in these groups no significant differences were found.

\section{Biological half time of selenium}

The Swedes are considered to have a relatively low intake of selenium. As the lung content of selenium is influenced by smoking habits (tobacco contains selenium) and not only by food intake, we have paid special attention to non-smokers. In non-smokers the selenium concentrations in lung tissue did not decline with time after the end of exposure (up to 23 years) which indicates a long biological half time $\left(\mathbf{R}^{2}\right.$ $=0.007)$, at least for some selenium compounds.

\section{Smoking}

It is interesting to note that cigarette smoke contains significant amounts of several of the metals investigated in this study. ${ }^{79}$ Looking at the lung cancer mortality reported, we find lower selenium tobacco concentrations $(0.16 \pm 0.05 \mu \mathrm{g} / \mathrm{g})$ in countries with a high incidence of lung cancer than in countries where the incidence is low $(0.49 \pm 0.22 \mu \mathrm{g} / \mathrm{g})$. This tendency has been supported by comparison with heavy smokers. ${ }^{80}$ Such differences due to selenium, however, have not been observed in our material.

\section{Exposure pattern}

The exposure patterns at the Rönnskär smelter are complex. As selenium has not been particularly under observation, few dust analyses are available, and so the dust load in exposed workers cannot be directly calculated. There are, however, two dominant trails through the smelter along which airborne selenium compounds are emitted:

(1) Copper roaster-arsenic refinery-selenium works; and

(2) Copper roaster-copper smelting furnacecopper converter-copper electrolytic refineryprecious metal works-selenium works.

Looking at the dominant worksites the workers have obviously been exposed to different concentrations of selenium over the years. The excretion rates show individual differences. In three of the seven cases of lung cancer we noted that, despite a considerable and continuous exposure in the course of their work, they had low selenium concentrations if their lung tissue at the time of death. Two othes. workers in the lung group had also been working at worksites with considerable exposure to selenium. One of them displayed moderately raised selenium lung tissue concentrations.

\section{Statistics}

The pairwise comparisons with Mann-Whitney's U test, testing the hypothesis of lower selenium concentrations in the lung cancer group makes a discussion of the problem of multiple significances necessary. The results of this analysis were statistically significant $(p<0.05)$ in 28 of the 35 tests (table 4). Of these, one or two most probably occurred by chance but the remaining significances are not to be $O$ explained by chance. The individual significances are, however, less interesting than the overall pic- 웅 ture which strongly rejects the null hypothesis. Thus the alternative hypothesis of lower lung selenium concentrations among the cases of lung cancer is $\tilde{N}$ favoured.

Financial support was given by the Swedish Work $N$ Environment Fund, project No 80/107.

Requests for reprints to: Dr L Gerhardsson, Department of Environmental Medicine, University of Umeå, S-901 87 Umeå, Sweden. 


\section{References}

' Scott ML. The selenium dilemma. J Nutr 1973;103:803-10.

${ }^{2}$ Muth $\mathrm{OH}$, Weswig PH, Whanger PD, Oldfield JE. Effect of feeding selenium-deficient ration to the subhuman primate (Saimiri sciureus). Am J Vet Res 1971;32:1603-5.

${ }^{3}$ Young VR. Selenium: a case for its essentiality in man. $N$ Engl J Med 1981;304:1228-9.

4 Martin JL, Spallholz JS. Selenium in the immune response. In: Proceedings symposium Selenium-Tellurium in the environment, University Notre Dame, Indiana, 1976. Pittsburgh: Industrial Health Foundation, 1976:204-25.

s Spallholz JE. Selenium: what role in immunity and immune cytotoxicity. In: Proceedings of the 2nd international symposium on selenium in biology and medicine, Texas Technical University, Lubbock, May 12-16, 1980:103-17.

- Harr JR, Exon JH, Weswig PH, Whanger PD. Relationship of dietary selenium concentration; chemical cancer induction; and tissue concentration of selenium in rats. Clin Toxicol 1973; 6:487-95.

'Thompson HJ, Becci PJ. Selenium inhibition of $\mathbf{N}-$ Methyl- $\mathrm{N}$-nitrosourea-induced mammary carcinogenesis in the rat. J. Natl Cancer Inst 1980;65:1299-1301.

${ }^{8}$ Medina D, Shepherd F. Selenium-mediated inhibition of mouse mammary tumorigenesis. Cancer Lett 1980;8:241-5.

4 Jacobs MM. Effects of selenium on chemical carcinogens. Prev Med 1980;9:362-7.

${ }^{10}$ Nordberg GF, Andersen O. Metal interactions in carcinogenesis: enhancement, inhibition. Environ Health Perspect 1981;40:65-81.

"Schrauzer GN, Ishmael D. Effects of selenium and of arsenic on the genesis of spontaneous mammary tumors in inbred $\mathrm{C}_{3} \mathrm{H}$ mice. Ann Clin Lab Sci 1974;4:441-7.

12 Shamberger RJ, Baughman FF, Kalchert SL, Willis CE, Hoffman GC. Carcinogen-induced chromosomal breakage decreased by antioxidants. Proc Natl Acad Sci 1973; 70: 1461-3.

13 Jacobs MM, Matney TS, Griffin AC. Inhibitory effects of selenium on the mutagenicity of 2-acetylaminofluorene (AAF) and AAF derivatives. Cancer Lett 1977;2:319-22.

14 Shamberger RJ, Beaman KD, Corlett CL, Kasten BL. Effect of selenium and other antioxidants on the mutagenicity of malonaldehyde. Fed Proc 1978;37:261.

is Greeder GA, Milner JA. Factors influencing the inhibitory effect of selenium on mice inoculated with Ehrlich ascites tumor cells. Science 1980;209:825-6.

${ }^{16}$ Rasco MA, Jacobs MM, Griffin AC. Effects of selenium on aryl hydrocarbon hydroxylase activity in cultured human lymphocytes. Cancer Lett 1977;3:295-301.

${ }^{17}$ Daoud AH, Griffin AC. Effects of selenium and retinoic acid on the metabolism of $\mathrm{N}$-acetylaminofluorene and $\mathrm{N}$ hydroxy-acetylaminofluorene. Cancer Lett 1978;5:231-7.

18 Griffin AC. Role of selenium in the chemoprevention of cancer. Adv Cancer Res 1979;29:419-42.

14 Marshall MV, Arnott MS, Jacobs MM, Griffin AC. Selenium effects on the carcinogenicity and metabolism of 2acetyl-aminofluorene. Cancer Lett 1979;7:331-8.

${ }^{20}$ Schwartz MK. Role of trace elements in cancer. Cancer Res 1975;35:3481-7.

${ }^{21}$ Chow CK. Nutritional influence on cellular antioxidant defense systems. Am J Clin Nutr 1979;32:1066-81.

22 Burk RF, Lawrence RA, Lane JM. Liver necrosis and lipid peroxidation in the rat as the result of paraquat and diquat administration. Effect of selenium deficiency. J Clin Invest 1980; 65: 1024-31.

${ }^{23}$ Kazantzis G. Role of cobalt, iron, lead, manganese, mercury, platinum, selenium and titanium in carcinogenesis. Environ Health Perspect 1981; 40:143-61.

${ }^{24}$ Glover J, Levander O, Parizek J, Vouk V. Selenium. In: Friberg
L, Nordberg GF, Vouk VB, eds. Handbook on the toxicology of metals. Amsterdam: Elsevier/North-Holland Biomedical Press, 1979: 555-77.

${ }^{25}$ Stewart RDH, Griffiths NM, Thomson CD, Robinson MF. Quantitative selenium metabolism in normal New Zealand women. Br J Nutr 1978; 40:45-54.

${ }^{26}$ Griffiths NM, Stewart RDH, Robinson MF. The metabolism of ['s $\mathrm{Se}$ ] selenomethionine in four women. $\mathrm{Br} J$ Nutr 1976;35: 373-82.

${ }^{27}$ Iyengar GV, Kollmer WE, Bowen HJM. The elemental composition of human tissues and body fuids. Weinheim, New York: Verlag Chemie, 1978.

${ }^{28}$ Masironi R, Parr R. Selenium and cardiovascular diseases. Preliminary results of the WHO/IAEA joint research programme. In: Proceedings symposium Selenium-Tellurium in the environment, University Notre Dame, Indiana, 1976. Pittsburgh: Industrial Health Foundation, 1976:316-25.

${ }^{24}$ Wester PO. Trace elements in heart tissue. Acta Med Scand 1965; suppl 439: 1-48.

${ }^{30}$ Wester PO, Brune D, Nordberg GF. Arsenic and selenium in lung, liver, and kidney tissue from dead smelter workers. $\mathrm{Br} J$ Ind Med 1981;38:179-84.

${ }^{31}$ Martin JL, Gerlach ML. Selenium metabolism in animals. Ann NY Acad Sci 1972;192:193-9.

${ }^{32}$ Shamberger RJ, Willis CE. Selenium distribution and human cancer mortality. CRC Crit Rev Clin Lab Sci 1971;2:211-21.

${ }^{33}$ Shamberger RJ, Tytko SA, Willis CE. Antioxidants and cancer. Part VI. Selenium and age-adjusted human cancer mortality. Arch Environ Health 1976;31:231-5.

${ }^{34}$ Schrauzer GN, White DA, Schneider CJ. Cancer mortality correlation studies III: Statistical associations with dietary selenium intakes. Bioinorganic Chemistry 1977;7:23-34.

${ }^{3 s}$ McConnell KP, Broghamer WL Jr, Blotcky AJ, Hurt OJ. Selenium levels in human blood and tissues in health and in disease. J Nutr 1975;105: 1026-31.

${ }^{36}$ Shamberger RJ, Rukovena E, Longfield AK, Tytko SA, Deodhar S, Willis CE. Antioxidants and cancer. I. Selenium in the blood of normals and cancer patients. J Natl Cancer Inst 1973;50: 863-70.

${ }^{37}$ Broghamer WL Jr, McConnell KP, Blotcky AL. Relationship between serum selenium levels and patients with carcinoma. Cancer 1976;37:1384-8.

${ }^{38}$ Willett WC, Morris JS, Pressel S, et al. Prediagnostic serum selenium and risk of cancer. Lancet 1983;ii: 130-4.

${ }^{34}$ Lee AM, Fraumeni JF Jr. Arsenic and respiratory cancer in man: an occupational study.J Natl Cancer Inst 1969;42:1045-52.

${ }^{40}$ Ott MG, Holder BB, Gordon HL. Respiratory cancer and occupational exposure to arsenicals. Arch Environ Health 1974;29:250-5.

4 Tokudome S, Kuratsune M. A cohort study on mortality from cancer and other causes among workers at a metal refinery. Int J Cancer 1976; 17:310-7.

42 Axelson O, Dahlgren E, Jansson C-D, Rehnlund SO. Arsenic exposure and mortality: a case-referent study from a Swedish copper smelter. Br J Ind Med 1978;35: 8-15.

${ }^{43}$ Higgins I, Welch K, Oh M, Bond G, Hurwitz P. Influence of arsenic exposure and smoking on lung cancer among smelter workers: a pilot study. Am J Ind Med 1981;2:33-41.

${ }^{44}$ Matanoski GM, Landau E, Tonascia J, et al. Cancer mortality in an industrial area of Baltimore. Environ Res 1981;25:8-28.

4s Wall S. Survival and mortality pattern among Swedish smelter workers. Int J Epidemiol 1980;9:73-87.

${ }^{46}$ Pershagen G, Wall S, Taube A, Linnman L. On the interaction between occupational arsenic exposure and smoking and its relationship to lung cancer. Scand $J$ Work Environ Health 1981;7:302-9.

${ }^{47}$ Nordberg GF, Pershagen G. Metal interactions in carcinogenesis-effects of mixed exposures on carcinogenic response. Toxicol Environ Chem 1984;9:63-78.

${ }^{48}$ Pershagen G, Nordberg GF, Björklund NE. Carcinomas of the 
respiratory tract in hamsters given arsenic trioxide and/or benzo(a)pyrene by the pulmonary route. Environ Res 1984;34:227-41.

${ }^{44}$ Baetjer AM. Pulmonary carcinoma in chromate workers. Arch Ind Hyg Occup Med 1950;2:487-504.

${ }^{\text {so }}$ Bidstrup PL, Case RAM. Carcinoma of the lung in workmen in the bichromates-producing industry in Great Britain. $\mathrm{Br} \mathrm{J}$ lnd Med 1956;13:260-4.

st Enterline PE. Respiratory cancer among chromate workers. J Occup Med 1974; 16:523-6.

s2 Langård S, Norseth T. A cohort study of bronchial carcinomas in workers producing chromate pigments. $\mathrm{Br} J$ Ind Med 1975;32:62-5.

${ }^{53}$ Davies JM. Lung-cancer mortality of workers making chrome pigments. Lancet 1978;i: 384.

s4 Sunderman FW Jr. A review of the carcinogenicities of nickel, chromium and arsenic compounds in man and animals. Prev Med 1976;5:279-94.

ss Langård S, Norseth T. Chromium. In: Friberg L, Nordberg GF, Vouk VB, eds. Handbook on the toxicology of metals. Amsterdam: Elsevier/North-Holland Biomedical Press, 1979: 383-97.

${ }^{\text {so }}$ Norseth T. Cancer hazards caused by nickel and chromium exposure. J Toxicol Environ Health 1980;6:1219-27.

${ }^{37}$ Norseth T. The carcinogenicity of chromium. Environ Health Perspect 1981;40:121-30.

s8 Frentzel-Beyme R. Lung cancer mortality of workers employed in chromate pigment factories. J Cancer Res Clin Oncol $1983 ; 105: 183-8$.

sy Degraeve N. Carcinogenic, teratogenic and mutagenic effects of cadmium. Mutat Res 1981;86:115-35.

${ }^{60}$ Piscator M. Role of cadmium in carcinogenesis with special reference to canccr of the prostate. Environ Health Perspect 1981;40:107-20.

61 Takenaka S, Oldiges H, König H, Hochrainer D, Oberdörster G. Carcinogenicity of cadmium chloride aerosols in $\mathrm{W}$ rats. $J$ Natl Cancer Inst 1983; 70:367-73.

${ }^{62}$ Friberg L, Kjellström T, Nordberg GF, Piscator M. Cadmium. In: Friberg L, Nordberg GF, Vouk VB, eds. Handbook on the toxicology of metals. Amsterdam: Elsevier/North-Holland Biomedical Press, 1979:355-81.

${ }^{63}$ Lemen RA, Lee JS, Wagoner JK, Blejer HP. Cancer mortality among cadmium production workers. Ann NY Acad Sci 1976;271:273-9.

64 Kazantzis G, Lilly LJ. Mutagenic and carcinogenic effects of metals. In: Friberg L, Nordberg GF, Vouk VB, eds. Handbook on the toxicology of metals. Amsterdam: Elsevier/NorthHolland Biomedical Press, 1979:237-72.

os Tsuchiya K. Lead. In: Friberg L, Nordberg GF, Vouk VB, eds. Handbook on the toxicology of metals. Amsterdam: Elsevier/ North-Holland Biomedical Press, 1979:451-84.
${ }^{\circ}$ Cooper WC, Gaffey WR. Mortality of lead workers. J Occup Med 1975;17:100-7.

${ }^{67}$ Cooper WC. Cancer mortality patterns in the lead industry. Ann NY Acad Sci 1976;271:250-9.

* Tola S. Occupational exposures and lung cancerepidemiological approaches. Eur J Respir Dis 1982;63, suppl 123: 128-38.

${ }^{64}$ Thaw $\mathrm{HH}$. Free radicals in cellular pathology. The infuence of oxygen and its metabolites on cultured cells. Linköping, Sweden: University of Linköping, 1983. (Medical dissertation No 161.)

${ }^{70}$ Bakka A, Endresen L, Johnsen ABS, Edminson PD, Rugstad HE. Resistance against cis-dichlorodiammineplatinum in cultured cells with a high content of metallothionein. Toxicol Appl Pharmacol 1981;61:215-26.

" Combs GF Jr, Scott ML. Nutritional interrelationships of vitamin E and selenium. BioScience 1977;27:467-73.

${ }^{12}$ Samsahl K, Wester PO, Landström O. An automatic group separation system for the simultaneous determination of a great number of elements in biological material. Anal Chem 1968;40:181-7.

${ }^{73}$ Wester PO, Brune D, Samsahl K. Radiochemical recovery studies of a separation scheme for 23 elements in biological material. Int J Appl Radiat Isot 1964;15:59-67.

${ }^{74}$ Lundberg E, Frech W, Lindberg I. Determination of lead in biological materials by constant-temperature electrothermal atomic absorption spectrometry. Anal Chimica Acta 1984; 160: 205-15.

is Harding-Barlow 1 . Studies on the trace element content of human tissues. Capetown: University of Capetown, 1961. (Doctoral dissertation.)

76 Perry HM Jr, Tipton IH, Schroeder HA, Cook MJ. Variability in the metal content of human organs. J Lab Clin Med 1962;60:245-53.

" Shamberger RJ. Relationship of selenium to cancer. I. Inhibitory effect of selenium on carcinogenesis. J Natl Cancer Ins 1970; 44:931-6.

${ }^{78}$ Hamilton EI, Minski MJ, Cleary JJ. The concentration and distribution of some stable elements in healthy human tissues: from the United Kingdom. Sci Total Environ 1972;1:341-74.

${ }^{74}$ Nadkarni RA, Ehmann WD. Transference studies of trace elements from cigarette tobacco into smoke condensate, and their determination by neutron activation analysis. In: Proceedings tobacco health conference, Lexington, Kentucky, 1970. Conference report 2. Lexington, KY: University of Kentucky. 1970:37-45.

${ }^{80}$ Bogden JD, Kemp FW, Buse M, et al. Composition of tobaccos from countries with high and low incidences of lung cancer. I. Selenium, Polonium-210, Alternaria, tar and nicotine. $J$ Natl Cancer Inst 1981;66:27-31. 